\title{
BUCCAL CELLS SUBMITTED TO THREE DIFFERENT STORAGE CONDITIONS BEFORE DNA EXTRACTION
}

\author{
Fernanda NEDEL ${ }^{1}$, Dárvi de Almeida ANDRÉ ${ }^{2}$, Isabel Oliveira de OLIVEIRA ${ }^{3}$, \\ Sandra Beatriz Chaves TARQUINIO ${ }^{4}$, Flávio Fernando DEMARCO 5
}

\author{
1- Undergraduate student, Federal University of Pelotas, Pelotas, RS, Brazil. \\ 2- DDS, Graduate student, Federal University of Pelotas, Pelotas, RS, Brazil. \\ 3- DDS, MSc, PhD, Adjunct Professor, Department of Physiology and Pharmacology, Federal University of Pelotas, Pelotas, RS, Brazil. \\ 4- DDS, MSc, PhD, Associate Professor, Department of Semiology and Clinic, Federal University of Pelotas, RS, Brazil. \\ 5- DDS, MSc, PhD, Associate Professor, Department of Operative Dentistry, Federal University of Pelotas, RS, Brazil.
}

Corresponding address: Prof. Dr. Flávio Fernando Demarco - Universidade Federal de Pelotas - Faculdade de Odontologia - Rua Gonçalves Chaves, no. 457 - 96015-560 - Pelotas - RS - Brasil - Phone: +55-53-3225-6741- Fax: +55-53-3225-5581- e-mail: flavio.demarco@pq.cnpq.br

Received: March 27, 2008 - Accepted: August 31, 2008

\begin{abstract}
$T_{\mathrm{h}}$

his study evaluated quantitatively and qualitatively the effect of the storage time of samples before the application of the cell lysis solution (CLS) for extracting DNA from buccal cells (BC). BC from the upper and lower gutter region were collected from 5 volunteers using special cytobrushes (Gentra), totaling 3 collections for each individual. In the control group ( $\mathrm{n}=10$ ), CLS was applied soon after $\mathrm{BC}$ collection. In the other two groups, samples were stored at room temperature $(\mathrm{n}=10)$ or at $4^{\circ} \mathrm{C}(\mathrm{n}=10)$. After CLS application, DNA was extracted according to the manufacturer's instructions (Puregene DNA Buccal Cell Kit; Gentra Systems, Inc.). The DNA obtained was evaluated by two calibrated blind examiners using spectrophotometry and analysis of DNA bands $(0.8 \%$ agarose gel electrophoresis). The obtained data were submitted to one-way ANOVA. The means and standard deviations for DNA extracted under immediate, room temperature and cooling temperature conditions were $3.5 \pm 0.7,3.0 \pm 0.6$ and $4.1 \pm 1.8 \mu \mathrm{g}$, respectively $(\mathrm{p}=0.385)$. No significant differences were found in relation to the amount of DNA for the different storage conditions. However, in the visual analysis of the DNA bands, no trace of DNA degradation was detected when CSL was applied soon after DNA collection, while DNA bands with degradation could be observed in the other groups. Within the limitations of the study, it may be concluded that CLS should be applied soon after DNA collection in order to obtain high-quality DNA from BC.
\end{abstract}

Key words: DNA. Oral mucosa. Temperature. Time.

\section{INTRODUCTION}

The interest in understanding the genetic basis of diseases and drug regimens has increased, requiring DNA isolation. Blood samples are an excellent source to obtain large amounts of genomic DNA ${ }^{8,10}$. However the extraction of DNA from buccal cells $(\mathrm{BC})$ is bringing a new perspective to obtaining $\mathrm{DNA}^{8}$. Compared to other methods, such as blood collection, it is a noninvasive collection method and is therefore better tolerated by adults, children and handicapped individuals. This procedure has low cost and does not require medical assistance (e.g.: nurse), so a wide population can be genotyped ${ }^{1,3,6,9}$.

Two types of procedures for BC collection are used: dry and wet. The wet method consist in swishing liquids in the mouth and spitting them into a collecting cup ${ }^{2}$. This procedure yields a higher amount and longer fragments of $\mathrm{DNA}^{2,4}$, requires more steps, is more cumbersome and has a higher cost ${ }^{8}$. Dry procedures use cytobrushes and buccal swabs $^{4}$. They are simpler, more cost effective ${ }^{8}$ and are considered less sensitive to the effect of long time storage at room temperature when compared to mouthwash, which may be crucial for multicenter studies ${ }^{6}$. According to a recent study, the use of cytobrushes appears to be the most appropriate manner to facilitate self-collection of human genomic DNA with good quality and high security when compared to the mouthwash method ${ }^{6}$.

Commercial kits are available to extract DNA from BC and they can provide sufficient DNA for genetic analysis. Nevertheless, due to logistic, financial, practical and methodological reasons, large studies often require the storage of BC samples before DNA extraction ${ }^{7}$. There is a lack of information in the literature regarding the best method to store BC after collection. Therefore, the purpose of this study was to evaluate quantitatively and qualitatively the effect of the storage time of samples before the application of the cell lysis solution (CLS) for extracting DNA from BC. 
IMMEDIATE

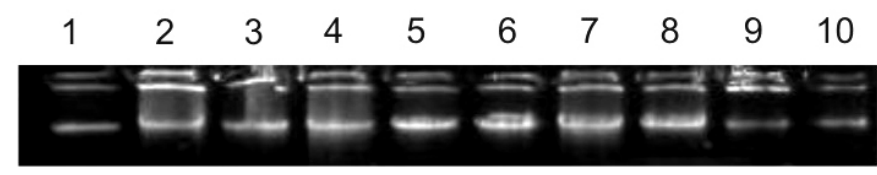

\section{ROOM TEMPERATURE}

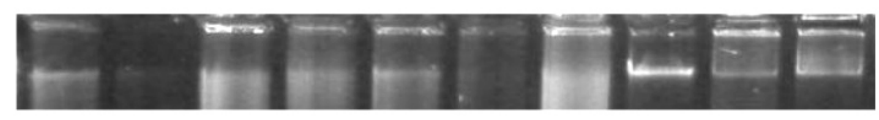

\section{COOLING}

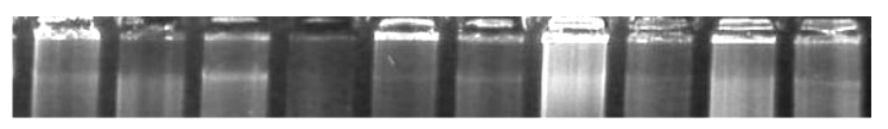

FIGURE 1- Quality of DNA evaluated by agarose gel electrophoresis. When the samples were processed immediately after collection, the DNA bands were strong and clear. When the samples were stored at room temperature or cooled, the quality of DNA decreased and the bands were degraded or absent

\section{MATERIAL AND METHODS}

The research protocol was reviewed and approved by the Research Ethics Committee of the Federal University of Pelotas, Brazil.

Five volunteers were selected to participate in the study and were submitted to three $\mathrm{BC}$ collections. In each collection, 2 BC samples were obtained, being one from the upper and one form the lower gutter region. Samples were collected using disposable special cytological brushes and the volunteers were instructed to brush and twirl each cytobrush for $30 \mathrm{~s}$ over the gutter region, which is the space between the gums and the inner portion of the lips and cheeks along the front and sides of the mouth. For all volunteers, the collections were performed in different anatomical regions of the oral cavity at the same time, with 5 days of interval between each collection.

The collected samples were treated in three different forms. In the control group $(n=10)$, immediately after the collection, the cytological brush containing the material was introduced in a microfuge tube that contained CLS. After 3 $\mathrm{h}$ in this solution, the samples were submitted to laboratory processing for DNA extraction. In the second group $(n=10)$, soon after collection, the cytobrush was placed in a microfuge tube, without CLS, and left undisturbed for $72 \mathrm{~h}$ at room temperature. Thereafter, CLS was applied and the samples were processed in the same way as in the control group. In the third group $(n=10)$, the collected samples remained in the microfuge tube for $72 \mathrm{~h}$ at $4^{\circ} \mathrm{C}$. After this period, CLS was applied and the samples were processed in the same way as in the control group.

All samples were processed following the manufacturer's instructions (Puregene DNA Buccal Cell Kit; Gentra Systems, Inc., Minneapolis, MN). According to the manufacturer, 0.2 to $2.0 \mu \mathrm{g} / \mathrm{brush}$ of DNA is expected to be obtained.

After processing of each sample, $20 \mu \mathrm{L}$ of solution was obtained. From this amount, $10 \mu \mathrm{L}$ were placed in a tube containing $90 \mu \mathrm{L}$ of Milli-Q water and the amount of DNA was read in a spectrophotometer (Eppendorf Biophotometer,
Hamburg, Germany), in which DNA concentration and purity was evaluated. The average from the two collections in each individual was obtained, with samples submitted to the same storage condition and the obtained data analyzed statistically by one-way ANOVA.

In order to ascertain the presence of high molecular weight DNA in the samples, the remaining $10 \mu \mathrm{L}$ of each sample were used to run $0.8 \%$ agarose gel electrophoresis at $2 \mathrm{~V} / \mathrm{cm}$ and were stained with ethidium bromide. The DNA degradation was observed by fragmentation of the samples compared against a known molecular weight marker. The visible bands were examined by two calibrated examiners that were not involved in the study.

\section{RESULTS}

The means and standard deviations for DNA extracted under immediate, room temperature and cooling temperature conditions were $3.5 \pm 0.7,3.0 \pm 0.6$ and $4.1 \pm 1.8 \mu \mathrm{g}$, respectively. The statistical analysis did not show statistically significant difference regarding DNA concentration among the three storage conditions $(\mathrm{p}=0.385)$.

Regarding the qualitative evaluation, differences in band patterns were observed in the agarose gel. In the sample processed immediately after BC collection, no degradation traces were observed (Figure 1). However, in the others groups with samples processed later under room and cooling temperature conditions, DNA degradation or absence of bands were observed (Figure 1).

\section{DISCUSSION}

This study is particularly relevant for large-scale epidemiological studies, where generally the laboratory is not available to process the genetic material immediately after collection in a field study. Therefore, sample storage is frequently necessary to prevent the loss of quantity or quality of the genetic material. 
Although BC samples give a smaller amount of DNA then blood samples, recently developed methods of genotyping use very small amounts of DNA what makes the collection of $\mathrm{BC}$ a viable source of genetic material with high quality. Furthermore blood collection is more invasive and not well tolerated by some patients, making easier the compliance in larger epidemiologic studies ${ }^{4,9}$. The amount of DNA material obtained from $\mathrm{BC}$ is dependent of the location, the force applied during collection and the patients' individual variations ${ }^{6}$. Another factor that is capable to influence the amount of material obtained is the time of collection. In the present study, the time of collection of $30 \mathrm{~s}$ was set for each site to avoid irritation to the patient's mucous membranes. This time was used by several studies ${ }^{3,9,11}$ since longer times are unviable, especially in studies involving children.

In order to avoid loss of material in the present study, the collections were made before volunteers had eaten or brushed their teeth, since the attrition of foods and toothbrush could reduce significantly the amount of material on the mucous membranes. The selection for the gutter region of the mouth instead of the inner cheek was based in a recent study by Saftlas, et al. ${ }^{9}$ (2004), where collection with cytobrushes in adult women from the gutter provided significantly larger amounts of DNA $(7.5 \mu \mathrm{g})$ than the standard method of brushing the inner cheeks $(3.8 \mu \mathrm{g})$. However, in the present study, the mean amount of DNA obtained from the gutter area was $3.5 \mu \mathrm{g}$, which is similar to the quantity obtained from the inner cheeks in Saftlas' et al. study. In addition, the value obtained in the present study is similar to that reported by Mulot, et al. ${ }^{6}$ (2005) using cytobrushes that were twirled in the inner cheek during $15 \mathrm{~s}$. The same author observed that there was no significant decrease of the DNA yield between 2, 5 and 7 days, while all samples were maintained at room temperature ${ }^{6}$. These results corroborate those of the present study, with no significant difference between the three methods of storage after material collection. In addition, for all methods, the amount of DNA was greater than 1 to $2 \mu \mathrm{g}$, which is considered adequate for epidemiological studies ${ }^{6,9}$.

The qualitative evaluation was based on the $0.8 \%$ agarose gel observation. A decrease in DNA quality was observed when the material was not immediately placed in CLS and processed, but was rather stored at room temperature or kept refrigerated until immersion in CLS and processing. Degradation of DNA bands was observed in the specimens processed lately. This could suggest that soon after collection of genetic material, the brushes should be placed immediately in the lysis solution to preserve the material's quality. King, et $a .^{5}$ (2002) verified the DNA quality using PCR amplification and observed that cytobrushes collections, contains DNA fragments for short and intermediate amplification primers, and poor results for large gene fragments. According to the authors, it might have occurred due to degradation of the DNA from the cytobrushes, suggesting that the period of storage is an important issue in DNA quality, which was reaffirmed by the findings of present study. However, we also observed that the degradation process could be minimized by immediately placing the samples in the CLS.
Finally, it is important to highlight that genetic material collection with cytobrushes has proved to be an effective and low cost method for the collection of genetic material for epidemiologic studies.

\section{CONCLUSION}

Within the limitations of this study it may be concluded that the amount of DNA obtained was not influenced by the method of storage prior to CLS application. However, the quality of the genetic material was more preserved when cell lysis was performed immediately after sample collection.

\section{REFERENCES}

1- Etter JF, Neidhart E, Bertrand S, Malafosse A, Bertrand D. Collecting saliva by mail for genetic and cotinine analyses in participants recruited through the Internet. Eur J Epidemiol. 2005;20(10):833-8.

2- Feigelson HS, Rodriguez C, Robertson AS, Jacobs EJ, Calle EE, Reid YA, et al. Determinants of DNA yield and quality from buccal cell samples collected with mouthwash. Cancer Epidemiol Biomarkers Prev. 2001;10(9):1005-8.

3- Garcia-Closas M, Egan KM, Abruzzo J, Newcomb PA, Titus-Ernstoff L, Franklin T, et al. Collection of Genomic DNA from Adults in Epidemiological Studies by Buccal Cytobrush and Mouthwash. Cancer Epidemiol Biomarkers Prev. 2001;10(6):687-96.

4- Heath EM, Morken NW, Campbell KA, Tkach D, Boyd EA, Strom DA. Use of Buccal Cells Collected in Mouthwash as a Source of DNA for Clinical Testing. Arch Pathol Lab Med. 2001;125(1):127-33.

5- King IB, Satia-Abouta J, Thornquist MD, Bigler J, Patterson RE, Kristal $\mathrm{AR}$, et al. Buccal cell DNA yield, quality, and collection costs: comparison of methods for large-scale studies. Cancer Epidemiol Biomarkers Prev. 2002;11(10):1130-3.

6- Mulot C, Stucker I, Clavel J, Beaune P, Loriot MA. Collection of human genomic DNA from buccal cells for genetics studies: comparison between cytobrush, mouthwash, and treated card. J Biomed Biotechnol. 2005;2005(3):291-6.

7- Ng DP, Koh D, Choo SG, Ng V, Fu Q. Effect of storage conditions on the extraction of PCR-quality genomic DNA from saliva. Clin Chim Acta. 2004;343(1-2):191-4.

8- Saab YB, Kabbara W, Chbib C, Gard PR. Buccal cell DNA extraction: yield, purity, and cost: a comparison of two methods. Genetic Testing. 2007;11(4):413-6.

9- Saftlas AF, Waldschmidt M, Logsden-Sackett N, Triche E, Field E. Optimizing buccal cell DNA yields in mothers and infants for human leukocyte antigen genotyping. Am J Epidemiol. 2004;160(1):77-84.

10- Silva RHA, Sales-Peres A, Oliveira RN, Oliveira FT, Sales-Peres SHC. Use of DNA technology in forensic dentistry. J Appl Oral Sci. 2007;15(3):156-61.

11- Woo JG, Sun G, Haverbusch M, Indugula S, Martin LJ, Broderick JP, et al. Quality assessment of buccal versus blood genomic DNA using the Affymetrix 500 K GeneChip. BMC Genet. 2007;8:79. 